w Poznaniu

przemek@amu.edu.pl

\title{
Morfologiczne wykładniki pozytywnych emocji w „Przewodniku Katolickim” z lat 1895-2005
}

Abstract: Przemysław Wiatrowski, Morfologiczne wykladniki pozytywnych emocji w „Przewodniku Katolickim" z lat 1895-2005 (Morphological Indicators of Positive Emotions in "Przewodnik Katolicki" in the Years 1895-2005). "Poznańskie Studia Slawistyczne" 9. Poznań 2015. Publishing House of the Poznań Society for the Advancement of the Arts and Sciences, pp. 169-188. ISSN 2084-3011.

The object of the linguistic analysis are articles published in the years 1895-2005 in „Przewodnik Katolicki" - one of the oldest Polish periodicals and the oldest Catholic weekly in Poland, which to a large extent has preserved its traditional line. The research conducted in this paper is of an empirical, material and interpretative character. Its purpose is the analysis of linguistic facts excerpted from „Przewodnik Katolicki” which were used by the magazine editors to express positive emotions. Only morphological indicators of positive emotions (inflectional expressive forms, morphological expressive forms) have been analyzed. Analyzing the expressive forms, the author reveals their factual emotional values coded in the elements constituting those constructions, i.e. inflectional morphemes and morphological formants. To achieve this goal he also takes into consideration other aspects of the process of expression. He includes both interactions between the constituent elements (the inner context) of inflectional and morphological structures and the activity of other components of an utterance or consituation which jointly organize the emotional meaning of expressive forms. The reconstructed senses are presented in the form of explications, following the ideas of Anna Wierzbicka and Stanisław Grabias, as analytical formulas equivalent with the defined constructions.

KeYwords: religious magazine; "Przewodnik Katolicki"; positive emotions; morphology; inflectional expressive form; morphological expressive form

\section{Wprowadzenie}

W 2010 roku ukazało się opracowanie Morfologiczne i leksykalne wykładniki negatywnych emocji $w$, Przewodniku Katolickim” z lat 1895-2005 (Wiatrowski 2010), które jest nieznacznie zmodyfikowaną wersją 
mojej rozprawy doktorskiej, przygotowanej pod kierunkiem profesora Stanisława Mikołajczaka. Jej przedmiotem - co sygnalizuje tytuł książki - są morfologiczne (fleksyjne, słowotwórcze) oraz leksykalne (nazwy emocji

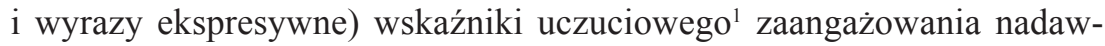
ców „Przewodnika Katolickiego” - czasopisma konfesyjnego, ukazującego się nieprzerwanie od niemal 120 lat. Jest to najdłużej wychodzący tygodnik katolicki w Polsce. I już ten fakt czyni z omawianego periody$\mathrm{ku}$ interesujący materiał badawczy (szerzej na ten temat cf. Wiatrowski 2010). Wcześniej żadne polskie pismo wyznaniowe nie doczekało się językoznawczej monografii.

W niniejszym artykule realizuję po części postulat zgłoszony w pracy z 2010 roku. Pisałem wówczas między innymi: ,zakres analiz lingwistycznych można ponadto poszerzyć o te elementy werbalne, które sygnalizują emocje pozytywne" (Wiatrowski 2010: 308). Odnosząc się do tych słów, obserwacji poddaję morfologiczne wykładniki pozytywnych uczuć ${ }^{2}$ (ekspresywizmy morfologiczne), pozostawiając opis pozostałych elementów językowych na inną okazję.

\section{Założenia teoretyczno-metodologiczne}

Prowadzone przeze mnie analizy oparte są na teorii ekspresji językowej Stanisława Grabiasa (cf. 1981), który od Anny Wierzbickiej przejął tezę o istnieniu skonwencjonalizowanych zachowań zewnętrznych sygnalizujących stany wewnętrzne (cf. Wierzbicka 1968: 98; 1969: 34-35). Zachowania te obejmują między innymi elementy językowe i sposoby ich organizowania mogące służyć do obrazowania osobowości nadawcy (cf. Grabias 1981: 17; 2001: 293). Badacz podkreśla, że „osobowość nadawcy ujawnia się najwyraźniej w emocjach, dlatego też badanie przejawów emocji pozostaje zasadniczym problemem teorii ekspresji” (Grabias 1981: 38). Ekspresją nazywa S. Grabias proces ujawniania się osobowości autora

\footnotetext{
${ }^{1}$ Terminy uczucie i emocja traktuję jako synonimy.

${ }^{2} \mathrm{Na}$ gruncie językoznawczym kryterium podziału uczuć na pozytywne i negatywne stanowi ocena zdarzenia wywołującego emocję, np. $x$ raduje się, że $z \rightarrow z$ jest dobre dla $x-a$ (uczucie pozytywne), $x$ jest zdenerwowany, że $z \rightarrow z$ jest złe dla $x$-a (uczucie negatywne) (cf. Mikołajczuk 2000: 120).
} 
wypowiedzi. Cechę znaku językowego (również komunikatu), będącą pochodną tego procesu, nazywa ekspresywnością (Grabias 1980: 479; 1981: 22; 2001: 292) $)^{3}$, a znakami ekspresywnymi są w ujęciu autora elementy semiotyczne wyrażające stosunek nadawcy do otaczających go zjawisk lub te, w których niezależnie od intencji mówiącego przejawiają się cechy jego osobowości. W grupie tak pojmowanych znaków ekspresywnych widzi badacz środki językowe, parajęzykowe oraz niejęzykowe (cf. Grabias 1981: 28; 2001: 292).

$\mathrm{Na}$ językową jednostkę ekspresywną składają się dwa podstawowe składniki semantyczne: intelektualny (logiczny) oraz ekspresywny (cf. Grabias 1981: 30). Drugi z wymienionych komponentów wnosi informacje nie tylko o emocjonalnym zaangażowaniu mówiącego; może także - między innymi - ewokować przynależność nadawcy do określonego środowiska (cf. Grabias 1981: 38) . W dalszej części artykułu interesować mnie będą wyłącznie środki językowe wyrażające uczucia (ekspresja w węższym sensie ${ }^{5}$ ). Ograniczam zatem wątek badawczy do analizy znaków emocjonalnych, w których poza intelektualnymi składnikami konstytutywnymi funkcjonuje ,naddany indeksalny komponent uczuciowego oglądu treści" (Grabias 1981: 33). Odwołanie się do zaproponowanego przez A. Wierzbicką (cf. 1968: 106; 1969: 42) i S. Grabiasa (cf. 1980; 1981) sposobu zapisu struktury semantycznej elementu ekspresywnego pozwala - dla przykładu - ująć znaczenie wyrazu ,ślamazara” w następujący sposób:

„ślamazara"

1. 'sądzę, że on jest nieudolny, działa bardzo wolno' (składnik intelektualny)

2. 'czuję z tego powodu emocje negatywne' (składnik ekspresywny).

${ }^{3}$ To rozróżnienie wprowadziła wcześniej Teresa Skubalanka (1972; 1973).

${ }^{4}$ O szerokim znaczeniu ekspresji pisze także Teresa Smółkowa (1989: 39-40). Zdaniem autorki strukturę semantyczną leksykalnej jednostki ekspresywnej wyznaczają komponenty intelektualne oraz sfera ekspresywna informująca o cechach stylistycznych jednostki. W węższym znaczeniu ekspresja ogranicza się wyłącznie do sygnalizowania uczuć nadawcy.

${ }^{5}$ Przyjęte tutaj rozumienie ekspresji zakłada, że jest ona procesem bezpośredniego lub pośredniego uzewnętrzniania emocji nadawcy (cf. Grzegorczykowa 1978: 118; także Lubaś 2003: 181). 
Zgodnie z wcześniejszą deklaracją, przedmiotem opisu czynię morfologiczne wykładniki pozytywnych emocji, czyli ekspresywizmy fleksyjne i słowotwórcze. Korpus tekstowy stanowiący podstawę rozważań jest identyczny z obranym w pracy poświęconej wskaźnikom negatywnych uczuć (Wiatrowski 2010: 20-22). Takie postępowanie badawcze umożliwi późniejsze szczegółowe porównania jakościowe (także w aspekcie diachronicznym) w obrębie całego zgromadzonego materiału językowego.

Pod uwagę biorę teksty prasowe (z wyłączeniem reklam, ogłoszeń oraz komunikatów o charakterze poradnikowym) zamieszczone w „Przewodniku Katolickim”, w których ujawniany jest pozytywny stosunek uczuciowy do prezentowanego fragmentu rzeczywistości. Wyekscerpowane $\mathrm{z}$ czasopisma cytaty pochodzą z czterech roczników tygodnika reprezentujących przedział czasowy 1895-2005. Są to roczniki: 1895 (52 numery), 1938 (52 numery), 1968 (52 numery), 2005 (52 numery oraz 2 numery specjalne $)^{6}$.

\section{Analiza materiału}

\subsection{Ekspresywizmy fleksyjne}

Autorzy „Przewodnika Katolickiego” odwołują się do dwóch zabiegów fleksyjnych, dzięki którym uzyskują emocjonalne nacechowanie wypowiedzi. Pierwszy polega na nadawaniu rzeczownikom męskoosobowym formy deprecjatywnej (cf. np. Bańko 2002: 147-148). W wypadku odnotowanej na kartach tygodnika słowoformy nie mamy jednak do czynienia z wyrażaniem deprecjacji:

(1) Dobrze im (Żydom) widać muszą nasze Poznaniaki na wschodzie sadła za skórą zalewać, że ci anonimy do nas przysyłają i udając patriotów, palcem Niemców jako wrogów nam wskazują, bylebyśmy tylko spokój im dali (1938/2/28)7.

\footnotetext{
${ }^{6} \mathrm{Na}$ temat kryteriów doboru poszczególnych roczników cf. Wiatrowski 2010: 20-21. W latach 1940-1955 tygodnik się nie ukazywał.

${ }^{7}$ Zachowuję oryginalną ortografię i interpunkcję. W nawiasach pojawiających się wewnątrz cytatów umieszczam uwagi uzupełniające kontekstową treść wypowiedzi. Każdy wyimek opatruję rokiem wydania czasopisma, numerem oraz stroną.
} 
O waloryzacji dodatniej nazwy „Poznaniaki” przesądza kontekst słowny $^{8}$, przede wszystkim sąsiadujący z rzeczownikiem zaimek dzierżawczy „nasze” (również w formie niemęskoosobowej), uwypuklający łączącą nadawcę, odbiorców oraz wymienionych „Poznaniaków” emocjonalną i ideową więź, nadto wyrażający aprobatę i poparcie dla działań wskazanej grupy, a także leksem prymarnie wartościujący (pozytywnie) „dobrze”.

Omawiana słowoforma, obecna w tekście z 1938 roku, niesie z sobą trzy typy informacji. Poza odsyłającym do określonego wycinka rzeczywistości pozajęzykowej komponentem intelektualnym ("mieszkaniec Poznańskiego') związanym z tematem fleksyjnym „Poznaniak-" i informacją semiczną ('mianownik, liczba mnoga, rodzaj niemęskoosobowy'), zawierają również składnik wskazujący na emocje. Strukturze gramatycznej „Poznaniaki” przypisać można komponent 'budzą zadowolenie, dumę’" Wykładnikiem formalnym znaczenia gramatycznego i emocjonalnego jest kumulujący funkcje morfem fleksyjny.

Drugi typ zjawisk fleksyjnych to nadawanie antroponimom formy liczby mnogiej. Wynikiem wskazanej operacji jest apelatywizacja nazwy własnej. Powołana w ten sposób do istnienia jednostka językowa ma charakter okazjonalny. Na jej strukturę semantyczną składa się wartość konotacyjna onimu, czyli - w świetle ustaleń Czesława Kosyla (1978: 136) - zespół sądów i wyobrażeń o denotacie nazwy.

W wyekscerpowanym materiale badawczym pojawiają się spluralizowane antroponimy wyrażające emocje o znaku dodatnim, będące wyrazem symbolicznej nobilitacji nosicieli tych nazw. Do omawianych onimów należą imiona starożytnych artystów, nazwiska bohaterów narodowych

${ }^{8}$ Odtwarzając znaczenie emocjonalne badanych jednostek językowych, uwzględniam zarówno interakcje pomiędzy elementami składowymi (kontekst wewnętrzny) struktur fleksyjnych i słowotwórczych, jak i aktywność pozostałych składników wypowiedzi czy konsytuację, które najczęściej współwyznaczają uczuciową barwę ekspresywizmów.

${ }^{9}$ „Rekonstrukcja znaczenia emocjonalnego ma w wypadku większości formułowanych (...) eksplikacji charakter aproksymacyjny wynikający przede wszystkim z niejednoznaczności ekspresywnej opisywanych jednostek oraz - rzadziej - z mało wyrazistego kontekstu. Stąd też w komponencie związanym z uczuciami ujmuję zazwyczaj kilka nazw emocji. Zdarza się jednak czasami, że ekspresywizmy ewokują różne, współwystępujące przeżycia wewnętrzne" (Wiatrowski 2010: 116). 
czy księży, których dokonania, czyny, postawy zapisały się w pamięci nadawców, np.:

(1) Niemcy, mieszkający w Polsce i umiejący po polsku, nawet w urzędach usiłują rozmawiać po niemiecku. A my?! Niechby tak Polacy w Niemczech próbowali z tej beczki. No, mieliby się z pyszna! Mój Boże! Ci Polacy w Niemczech - ile oni muszą wycierpieć i przetrzymać dla polskości! To prawdziwi bohaterzy - Drzymałowie! (1938/36/600).

(2) Krzewił Przewodnik zawsze wielkie uznanie i cześć głęboką dla działaczy narodowych, w jakimkolwiek by się znaleźli obozie. A dzięki Bogu miał świat i Polska aż do ostatnich czasów swoich bohaterów. Do takich wielkich, niezwykłych już bohaterów należał ks. kanonik Świeykowski, proboszcz w Gorlicach w Małopolsce. (...) Takich Świeykowskich było dzięki Bogu więcej, choć nie w tych rozmiarach (1938/22/362).

(3) Rzeźby wieku XIII mówią, że chrześcijański Zachód miał cały szereg Fidiaszów. Ich dzieła miały być księgą pouczającą prosty lud. Podziwiamy dziś wrażliwość owego ludu, który umiał się poznać na tych arcydziełach i z nich uczyć (1968/13/117).

Wspólna wiedza o świecie i jednakowy system wartości adresata wypowiedzi oraz jej twórcy to warunek zgodnej z intencją autorów kwalifikacji denotatów jednostek językowych „Drzymałowie”, „Świeykowscy”, „Fidiaszowie” przez odbiorcę. Potęgujące zazwyczaj emocje otoczenie leksykalne (,prawdziwi bohaterzy”, „wielkie uznanie” i „cześć głęboka”, „wielcy, niezwykli bohaterzy”, ,arcydzieła” i in.) oraz odwołanie się do kontekstu historycznego i kulturowego, ściśle wyznaczonego przez czas powstania i funkcjonowania analizowanych struktur słownych, umożliwiają odczytanie zamiarów nadawcy, przywołanie odpowiednich asocjacji (wartości konotacyjnych) wiążących się z użytymi nazwami. W większości przykładów wartość konotacyjna mian „Drzymała”, „Świeykowski”, „Fidiasz” została wskazana eksplicite za pomocą waloryzującej pozytywnie leksyki: „,prawdziwi bohaterzy”, „,działacze narodowi”, „wielcy, niezwykli bohaterzy”, „arcydzieła”. W przykładzie (2) kontekst informuje wprost o rodzaju wyrażanych spluralizowaną nazwą uczuć: ,wielkie uznanie i cześć głęboka”. Dodać ponadto należy, iż jednostki „Drzymała” oraz „Fidiasz” charakteryzują się znacznie większym stopniem ustabilizowania asocjacyjnych znaczeń kulturowych niż miano „Świeykowski”. 
Próbę zaprezentowania procesu doraźnej, tekstowej apelatywizacji (cf. Chlebda 1995) antroponimów sygnalizujących pozytywne uczucia przedstawia poniższa tabela.

Tabela. Apelatywizacja tekstowa osobowych nazw własnych ${ }^{10}$

\begin{tabular}{|c|c|c|c|}
\hline Antroponim & $\begin{array}{c}\text { Wartość } \\
\text { konotacyjna } \\
\text { antroponimu }\end{array}$ & $\begin{array}{l}\text { Apelatyw } \\
\text { tekstowy }\end{array}$ & $\begin{array}{c}\text { Eksplikacja apelatywu } \\
\text { tekstowego }\end{array}$ \\
\hline Drzymała & bohater, patriota & „Drzymałów” & $\begin{array}{l}\text { 'bohaterzy, patrioci' + } \\
\text { 'budzą z tego powodu } \\
\text { zadowolenie, podziw, dumę' }\end{array}$ \\
\hline Świeykowski & $\begin{array}{l}\text { działacz narodowy, } \\
\text { bohater }\end{array}$ & „Świeykowskich” & $\begin{array}{l}\text { 'działacze narodowi, } \\
\text { bohaterzy’ + 'budzą z tego } \\
\text { powodu uznanie, cześć' }\end{array}$ \\
\hline Fidiasz & $\begin{array}{l}\text { wybitny artysta } \\
\text { rzeźbiarz }\end{array}$ & „Fidiaszów” & $\begin{array}{l}\text { 'znakomici rzeźbiarze' } \\
\text { + 'budzą z tego powodu } \\
\text { podziw, zachwyt' }\end{array}$ \\
\hline
\end{tabular}

\subsection{Ekspresywizmy słowotwórcze}

Emocjonalne zabarwienie wypowiedzi uzyskiwane jest także poprzez mechanizmy derywacyjne polegające na dodawaniu do różnych - neutralnych bądź już nacechowanych aksjologicznie i/lub emocjonalnie - części mowy (przede wszystkim rzeczowników, rzadziej przymiotników) ekspresywnych formantów. W zgromadzonym materiale tekstowym zdecydowanie dominują emocjonalizmy słowotwórcze tworzone za pomocą następujących ekspresywnych przyrostków (inwarianty traktuję jako formanty

${ }^{10}$ „Wartość konotacyjną poszczególnych antroponimów ustalam na podstawie całego kontekstu komunikacyjnego, przede wszystkim sięgam do innych wypowiedzi na łamach tygodnika w zbliżonym czasie opublikowanych (wykraczam więc poza kontekst syntagmatyczny onimów). Analizowanych apelatywów nie poddaję konsekwentnie lematyzacji ze względu na niemożność ustalenia w większości wypadków właściwej (osobowej lub rzeczowej) postaci mianownika liczby mnogiej. Eksplikacja nomen appellativum zawiera komponent intelektualny oraz emocjonalny" (Wiatrowski 2010: 121). 
samodzielne): ,-ek”, „-ka”, „-ko”, „-ina/-yna”, „-cio”, ,-isko”/,-ysko”, „-aszek”, ,-uś”, ,-yczka”, ,-utka”, „-eńka”. Wymienione konstrukcje sufiksalne poddaję analizie.

SUFIKS ,-EK”

Zaledwie w dwóch odnalezionych na kartach tygodnika derywatach przyrostek ,-ek” jest nośnikiem znaczeń pozytywnych:

(4) Starczą one (słowa z Ewangelii o życiu św. Rodziny) jednak, by świat spragniony ciepła rodzinnego spoglądał na zacisze domku nazaretańskiego z wiarą i nadzieją (...) $(1938 / 2 / 18)$.

(5) Ale chyba nikt nie jest taki naiwny, żeby myśleć iż ten kleryczek Angelo Giuseppe Roncalli (Jan XXIII), który w 12 roku życia przeszedł 1893 r. do niższego seminarium z podgórskiej wioski Sotto il Monte, posiadał już w doskonałym stopniu i zharmonizowaniu te wszystkie wspaniałe cechy, którymi później zdobywał serca ludzi na całym świecie, że nie musiał walczyć z ,wadami swoich cnót” wynikającymi z naszej wspólnej nędzy ludzkiej owego pokutującego wciąż w nas grzechu pierworodnego $(1968 / 19 / 174)$.

W formancie obecnym w ekspresywizmie „kleryczek” aktualizują się dwie funkcje: sufiks nie tylko zabarwia derywat afektywnie, ale zawiera również sem modyfikacji kwantytatywnej (sąsiedztwo wyrazowe potwierdzałoby tę tezę: „w 12 roku życia”). Niejednoznaczny jest z kolei przyrostek budujący konstrukcję domek. Trudno orzec, czy poza ewokowaniem informacji o uczuciach pełni też funkcję intelektualną.

Derywatom utworzonym segmentem ,-ek” można na podstawie przeanalizowanych wypowiedzi przypisać następujące eksplikacje ${ }^{11}$ :

„domek”

1. '(mały) dom'

2. 'budzi miłość, cześć'

${ }^{11}$ „Na eksplikacje formacji z formantami kumulującymi funkcje pojęciowe i emocjonalne składają się znaczenia strukturalne oraz semy emocji (wnoszone przez formanty lub jednocześnie przez formanty i tematy słowotwórcze). W wypadku derywatów utworzonych wyłącznie w celu uzewnętrznienia stanów afektywnych komponenty wskazujące na uczucia są elementem znaczeń słowotwórczych. Niejednoznaczne (w tym metaforyczne) wyrazy motywujące obudowuję dodatkowymi, uściślającymi informację semantyczną ekwiwalentami” (Wiatrowski 2010: 136). 


\section{„kleryczek”}

1. '(mały), młody kleryk'

2. 'budzi sympatię'.

\section{SUFIKS „-KA”}

Implikujący rodzaj żeński przyrostek ,-ka” buduje w tygodniku denominalne formacje deminutywno-ekspresywne motywowane rzeczownikiem osobowym oznaczającym desygnat należący do sfery sacrum. Konstrukcje te są obligatoryjnie stosowane dla okazania pozytywnych uczuć. Chodzi o sporą grupę melioratywów bazujących na rzeczowniku „Panna”:

(6) Tak obrazy Matki Boskiej i innych Świętych Pańskich, jeżeli mają nasze nabożeństwo i nasze dziecięce przywiązanie do Najśw. Panienki prawdziwie uszlachetnić, i na wzór Świętych nasze serce do Boga w świętem zwracać uczuciu, powinny być nacechowane wzniosłą, chrześcijańską pięknością (1895/23/185).

(7) Ileż to uzdrowień od tego czasu dokonało się w Lourdes! Iluż to ludzi zostało dotkniętych łaską Bożą! Iluż chorych stało się zdrowymi, niewierzących gorącymi wielbicielami Najśw. Panienki! (1938/50/842).

(8) Przenajświętsza Panienka jest w nim (Katechizmie Kościoła Katolickiego) przedstawiona także jako mieszkanie (dla) Ducha Świętego (2005/5/14).

Jednostka „Panienka” wraz z wartościującym superlatywem („najświętsza”) i ekscesywem (,przenajświętsza”) wyraża przywiązanie (zwerbalizowane w [7] fragmencie gerundium komunikującym o uczuciu), przede wszystkim jednak umiłowanie, cześć i najwyższe uwielbienie dla Matki Bożej ${ }^{12}$.

Segmentem ,-ka” urabiane są również odantroponimiczne hipokorystyka (cf. Domin 2000). Proces ich tworzenia determinowany jest przede wszystkim względami emocjonalnymi:

${ }^{12}$ Wątpliwości budzi morfologiczny (słowotwórczy) status jednostki językowej „Panienka" odnoszącej się do matki Jezusa. Występuje ona niezwykle często w takiej spetryfikowanej formie, co sugerowałoby jej leksykalizację. Sąd ten można również odnieść do struktur typu „Dzieciątko” (Boże), „Dziecina” (Boża). Przyjmuję jednak tezę o pełnej podzielności formalnej i semantycznej wszystkich wymienionych formacji, ponieważ na łamach czasopisma funkcjonuje także forma podstawowa („Najświętsza”) Panna, a konstrukcje „Dzieciątko”/,Dziecina”/„Dziecię” stosowane są wymiennie. Dodatkowy ładunek emocjonalny niesiony przez sufiksy (oraz formant paradygmatyczny) jest czytelny. 
(9) To, co było niemożliwe za życia, spełniło się po śmierci św. Tereski. Wszędzie tam, gdzie docierają jej relikwie, podążają tłumy ludzi, które proszą o jej wstawiennictwo, a potem cieszą się jego owocami (2005/28/14).

Nie da się jednak wykluczyć współudziału pierwiastka intelektualnego w derywowaniu niektórych ekspresywizmów imiennych:

(10) W tym właśnie miejscu 11 lutego 1858 roku czternastoletnia Bernadetka Soubirous ujrzała Piękną Panią (1968/6/63).

Informacja przyjmująca postać przymiotnika (,czternastoletnia”) pozwala wnioskować, że deminutywny formant pełni w derywacie „Bernadetka" nie tylko funkcję afektywną. Równie istotne jest jego znaczenie wskazujące może nie tyle na wielkość, ile na młody wiek opisywanej osoby.

Szczegółową charakterystykę emocjonalnych znaczeń wyrażanych przez derywaty konstruowane formantem ,--ka" przedstawia zestawienie:

„Panienka”

'z przywiązaniem, miłością, uwielbieniem, czcią o Pannie (Najświętszej)' "Tereska"

'z miłością, czcią o Teresie'

„Bernadetka”

1. '(mała), młoda Bernadeta'

2. 'budzi sympatię, szacunek'.

SUFIKS ,-KO”

Wymieniony przyrostek konstytuuje na łamach periodyku dość liczne deminutywa emfatyczne motywowane tym samym rzeczownikiem. Odnoszą się one do małego Jezusa, np.:

(11) „Pasterka” zgromadza wszystkich prawie wiernych do świątyni, a oni w śpiewie kolęd chwalą nowonarodzone Boże Dzieciątko. Tu i owdzie stawiają po kościołach ,jasełka”, czyli żłóbek na przypomnienie owego żłóbka w ubożuchnej stajence betlehemskiej, w którym spoczywał Zbawiciel świata. I tu znowu wielcy i mali na kolanach ze czcią otaczają świętą Dziecinę (...) (1895/51/413).

(12) Odkąd pojawiło się na świecie Dzieciątko Boże i „nazwano Imię Jego Jezus”, „nie masz w żadnym innym zbawienia" (1938/1/2). 
(13) Nad prymitywną kaplicą opodal Greccio, w której przedstawioną została pierwsza szopka betlejemska, wzniesiono kościół na cześć św. Franciszka, a na skale, gdzie spoczywało Dzieciątko Jezus wystrugane z drzewa, ustawiono ołtarz. W tym samym miejscu, na którym zostało złożone Dzieciątko Betlejemskie, na najuboższym tronie najuboższego śmiertelnika. Tam gdzie Biedaczyna z Asyżu pieścił Nowonarodzonego $(1968 / 4 / 39)$.

(14) W betlejemskim Dzieciątku i w klęczącym przed Nim sędziwym Papieżu był z nami ten sam Bóg, którego spotykamy na ołtarzach (2005/1/5).

Duży ładunek emocjonalny derywatu „Dzieciątko"13 jest wynikiem połączenia pozytywnie nacechowanego tematu słowotwórczego, który odnosi się do Syna Bożego, z deminutywno-ekspresywnym formantem. Wzmocnienie, i tak już przecież silnego zabarwienia afektywnego, uzyskują autorzy poprzez otaczające derywaty przydawki o stałej w tygodniku wartości konotacyjnej: „Boże”, „Jezus”, „Betlejemskie”/,,betlejemskie".

\section{Eksplikacja:}

„Dzieciątko"

'z miłością, czcią o Dziecięciu (Bożym)'.

\section{SUFIKS „-INA"/,-YNA”}

Przyrostek ,,-ina”/,-yna” - podobnie jak segment „-ko”- przyłączany jest najczęściej do tematu słowotwórczego, który odsyła do rzeczywistości sakralnej. Denotuje bowiem małego Jezusa. W takiej konfiguracji uaktywnia się wyłącznie pozytywna wartość emocjonalna omawianego sufiksu, np.:

(15) „Pasterka” zgromadza wszystkich prawie wiernych do świątyni, a oni w śpiewie kolęd chwalą nowonarodzone Boże Dzieciątko. Tu i owdzie stawiają po kościołach ,jasełka”, czyli żłóbek na przypomnienie owego żłóbka w ubożuchnej stajence betlehemskiej, w którym spoczywał Zbawiciel świata. I tu znowu wielcy i mali na kolanach ze czcią otaczają świętą Dziecinę (...) (1895/51/413).

(16) Nakrywając stół wigilijny, od najdawniejszych czasów rozściełano w Polsce pod obrusem nieco siana na pamiątkę sianka, na którym Boża Dziecina w żłóbku spo-

${ }^{13}$ Za Bogusławem Kreją (1969: 99) wywodzę analizowaną formację słowotwórczą od rzeczownika „dziecię” (z głównym tematem fleksyjnym „dziecięć-” wyabstrahowanym z całego paradygmatu). 
czywała. Piękny ten zwyczaj nie przyczynia żadnych kosztów - i powinien być praktykowany w każdym domu, gdyż przypomina nam przy stole, (...) aby w radosnym i podniosłym nastroju uczcić Dzieciątko Jezus (1938/52/878).

(17) Ks. Arcybiskup w przemówieniu kończącym uroczystość kolędową mówił o radości, przepełniającej serca wiernych przybyłych na ten wieczór, radości płynącej z Betlejemskiego Żłóbka, przed którym dzieci i młodzież złożyły Bożej Dziecinie ofiarę miłości i pracy $(1968 / 5 / 43)$.

(18) Z ogromnym uznaniem patrzę na ciężką pracę i wielkie zaangażowanie mieszkańców wsi (Jodłowej), przy budowie nowej świątyni. Szczególnie podziwiam pracę ks. kustosza Franciszka Cieśli. Podziwiam również jego życzliwość i gościnność dla pielgrzymów, pracę duszpasterską w parafii oraz troskę o rozwój kultu Bożej Dzieciny $(2005 / 52 / 19)$.

Zauważalne jest podobieństwo funkcjonalne między formacją „Dziecina” a omówioną wcześniej konstrukcją „Dzieciątko”. Obydwa derywaty oznaczają identyczny obiekt rzeczywistości pozajęzykowej, wyrażają podobne emocje związane z przynależnością desygnatu do sfery transcendentnej, która uruchamia zespół pozytywnych konotacji z tym desygnatem skorelowanych. Dodanie zaś emocjonalnego przyrostka uwydatnia uzewnętrzniane uczucia.

Wartość ekspresywna niektórych formacji z ,-ina”/,-yna” implikowana jest dodatkowo poprzez towarzyszące tym formacjom przydawki, np.:

(19) Nie było skromniejszego życia nad jego (Wincentego Pallottiego) życie. (...) Ten lichy proboszczyna był więc najsławniejszym spowiednikiem Wiecznego Miasta $(1938 / 19 / 308)$.

Przymiotnik ,lichy” (z aktualizowanym znaczeniem ‘ubogi') wskazuje na takie cechy prezentowanej osoby, które mogą budzić wzruszenie, ale też szacunek i podziw (szerszy kontekst sugeruje taką interpretację).

Eksplikacje:

„Dziecina”

'z miłością, czcią o Dziecku (Bożym)'

,proboszczyna”

'ze wzruszeniem, szacunkiem, podziwem o proboszczu'. 


\section{SUFIKS ,-CIO”}

Sufiks ,-cio” należy do formantów hipokorystycznych. Obsługuje apelatywa oraz osobowe nazwy własne (imiona). Derywaty antroponimiczne urobione tym przyrostkiem mają często podwójną motywację, np. „Stefcio" < „Stefan”, „Stefek”; „Tomcio” < „Tomasz”, „Tomek”. Przyjmuję tutaj pochodność imiennych hipokorystyków od konstrukcji zdeminutywizowanych („,Tomcio” < „Tomek”) (cf. np. Dobrzyński 1988: 19-20).

W wynotowanym z „Przewodnika Katolickiego” z 1938 roku fragmencie trzykrotnie poświadczone jest spieszczenie tego samego imienia męskiego:

(20) Jeśli zaś koniecznie chcecie ujrzeć „ideowca”, ja go wam wskażę. Jest nim 9-letni Jurcio Szukalski, ministrant i gorący wielbiciel zamordowanego kapłana! Kiedy po strzałach wszczął się ów straszny popłoch w kościele, kiedy z niesłychanym zgiełkiem wszystko rzuciło się do bramy, kiedy zbrodniarz wskoczywszy na niską ambonę zawołał: niech żyje komuna! Jurcio Szukalski wypadł z zakrystii. Natychmiast porwała go fala pierzchających. Ale tylko na chwilę. Bo doszedłszy do miejsca, na którym w krwi broczył ugodzony kulami kapłan, czym prędzej cofnął się do zakrystii, powyszukiwał szybko przybory do Ostatniego Namaszczenia Olejami św. i trwał wśród owego okropnego zgiełku i zamieszania na posterunku tak długo, dopóki nie wręczył przyborów przywołanemu kapłanowi, by ten bez chwili straty mógł oddać zamordowanemu koledze ostatnią przysługę! Tak mały, a już tak wielki ten Jurcio Szukalski! (1938/11/161).

Wypełnienie komunikatu środkami pozytywnie waloryzującymi (systemowo: przede wszystkim wyrażenie „tak wielki” i tekstowo: wartościowanie w implikaturze) czyny ministranta wpływa na emocjonalną jakość formantu antroponimicznego. Eksplikacja formacji przybiera postać: 'z sympatią, podziwem, zachwytem o Jurku'.

\section{SUFIKS ,-ISKA”}

W analizowanym korpusie tekstowym występuje tylko jeden derywat ze wskazanym przyrostkiem zawierającym morfem fleksyjny wskazujący na liczbę mnogą rzeczownika:

(21) Kraj (Ameryka Południowa) zresztą na wskroś katolicki, a jego mieszkańcy poczciwe ludziska, ale raz poraz szajka łotrzyków - masonów, niezadowolona położeniem rzeczy, pragnąc obalić dotychczasowy rząd, podburza kłamstwem lud do rewolucji, a opanowawszy sama rząd kraju, natychmiast zwraca się wrogo przeciw Kościołowi $(1895 / 28 / 224)$. 
Szukając odpowiedzi na pytanie, wykładnikiem jakich wartości emocjonalnych jest omawiany przyrostek, trzeba zwrócić uwagę na towarzyszącą formacji prepozycyjną przydawkę, która uwypukla dodatnie cechy charakteryzowanej osoby (,,poczciwe ludziska”).

Eksplikacja:

„ludziska”

'z sympatią o ludziach'.

\section{SUFIKS ,-ASZEK”}

Sufiks „-aszek” pełni niemal wyłącznie funkcję ekspresywną. Występuje w konstrukcjach motywowanych głównie przez nazwy osób (cf. Grzegorczykowa, Puzynina 1979: 177). Należy do formantów melioratywnych silnie zabarwionych uczuciowo (cf. Siatkowska 1967: 167; Dobrzyński 1988: 14).

Materiał badawczy zawiera urobiony sufiksem ,-aszek” ekspresywizm hipokorystyczny nazywający Jezusa:

(22) Już jako dwunastoletni młodzieniaszek wykładał Pan Jezus uczonym żydowskim Pismo św. w świątyni jerozolimskiej (...) (1895/27/215).

Eksplikacja:

„młodzieniaszek”

'z sympatią, miłością o młodzieńcu'.

\section{SUFIKS ,-UŚ”}

Hipokorystyczny przyrostek ,-uś” tworzy w „Przewodniku Katolickim” ekspresywizm osobowy odnoszący się do Istoty Boskiej:

(23) Bóg posyła swojego Ducha do każdego z nas. Mocą Jego Ducha otrzymujemy przebaczenie grzechów. W Nim mamy życie. On nas uczy mówić do Boga „Abba, Tatusiu!" (2005/41/15).

W spetryfikowanej (występującej w znanej pieśni religijnej) formule inwokacyjnej Abba, Ojcze nadawca wymienił polski ekwiwalent aramejskiego słowa „Abba” na wyrazistą pod względem ekspresywnym jednostkę hipokorystyczną „Tatuś”, która zmniejsza dystans między mówiącym 
(mówiącymi) a adresatem apostrofy - Bogiem. Oto jej eksplikacja: 'z miłością, uwielbieniem o Tacie (Bogu)'.

\section{SUFIKS ,-YCZKA”}

Komponowany przyrostek ,-iczka”/,-yczka” występuje w odrzeczownikowej nazwie żeńskiej. Wypowiedź, w której derywat został odnotowany, świadczy o tym, że omawiany sufiks pełni wyłącznie funkcję ekspresywną (brak funkcji deminutywnej):

(24) (...) w podeszłym wieku siostra Fortunata, choć pomarszczona i zgarbiona, pozostała wciąż sobą, tą kochaną uczynną siostrzyczką, która wciąż innym pomaga (1968/9/87).

Określenie typu i stopnia natężenia emocji, wywoływanych przez podmiot pierwszego zdania składowego (,siostra Fortunata”), możliwe jest dzięki niemal wszystkim innym elementom językowym wypowiedzi: implikującym jednocześnie podziw i wzruszenie sformułowaniom: „w podeszłym wieku”, „choć pomarszczona i zgarbiona”, „wciąż innym pomaga” oraz wartościującym leksemom „kochana”, „uczynna”.

Eksplikacja:

„siostrzyczka"

'z sympatią, wzruszeniem, podziwem o siostrze (zakonnej)'.

\section{SUFIKS ,-UTKA”}

Przyrostek ,,-utka” buduje w badanym materiale derywat odprzymiotnikowy, w którym z jednej strony intensyfikuje cechę zawartą w podstawie słowotwórczej, z drugiej zaś - zabarwia utworzoną formację emocjonalnie (cf. Bogusławski 1991: 174):

(25) Prasa katolicka donosi o pewnym zdarzeniu, które świadczy, że religijność narodu francuskiego umie zdobyć się na ofiary. Mianowicie pewna młodziutka zakonnica ze zgromadzenia sióstr dominikanek (...) dowiedziawszy się któregoś dnia, że poszukuje się 6 misjonarek na wyjazd do trędowatych do Afryki południowej, zgłosiła się bezzwłocznie pod wskazanym adresem (1938/10/151).

Tematyka fragmentu (wyjazd młodej zakonnicy na misję do chorych na trąd w Afryce), realizowana m.in. środkami językowymi wyposażonymi 
w łatwy do odczytania znak aksjologiczny (,,religijność narodu francuskiego umie zdobyć się na ofiary”; ,na wyjazd do trędowatych [...] zgłosiła się bezzwłocznie"), pozwala na umiejscowienie ekspresywnej barwy sufiksu po dodatniej stronie skali emocji.

Eksplikacja:

„młodziutka (zakonnica)”

1. 'bardzo (bardzo, bardzo) młoda'

2.'budzi sympatię, podziw'.

\section{SUFIKS „-EŃKA"}

Ostatni sufiks posłużył autorowi wypowiedzi do skonstruowania przymiotnika o znaczeniu deminutywnym (cf. Kreja 1999: 186), któremu towarzyszy informacja o emocjonalnej postawie autora. Odnotowana formacja zajmuje pozycję przydawki określającej antroponim odnoszący się do przyszłej błogosławionej:

(26) Przyjściem swojem na świat przyniosła maleńka Jolenta wiele radości i pociechy rodzicom swoim, którzy widzieli w tem szczególniejszy dowód łaski Boga nad sobą $(1895 / 2 / 5)$.

Eksplikacja:

„maleńka (Jolenta)"

1. 'bardzo (bardzo, bardzo) mała'

2. 'budzi sympatię'.

\section{Podsumowanie}

Inwentaryzacja morfologicznych wykładników pozytywnych emocji wykorzystywanych przez nadawców „Przewodnika Katolickiego” z lat 1895-2005 pozwala na sformułowanie kilku spostrzeżeń.

Nie ulega wątpliwości, że pod względem częstości występowania dominują ekspresywizmy słowotwórcze. Zabiegi fleksyjne mają w badanym materiale śladowe poświadczenia. Polegają one na zastąpieniu - w zakresie rzeczowników osobowych - końcówką rzeczową morfemu gramatycznego wskazującego na rodzaj męskoosobowy (np. „Poznaniaki”) oraz na pluralizacji jednostkowych osobowych nazw własnych, czego efektem jest 
ich doraźna, sytuacyjna apelatywizacja (np. „Świeykowskich”, „Drzymałów”, „Fidiaszów”).

Znacznie obszerniejsza liczebnie jest grupa emocjonalizmów słowotwórczych, obejmująca przede wszystkim derywaty rzeczownikowe oraz - w znacząco mniejszym stopniu - przymiotnikowe. Te ostatnie konstytuowane są sufiksami „-utka” („młodziutka”) i ,-eńka” (,maleńka”) przyłączanymi do neutralnych tematów słowotwórczych.

Formacje rzeczownikowe to wynik zastosowania kilku technik derywacyjnych, nade wszystko sufiksacji. W wyekscerpowanych rzeczownikach słowotwórczo pochodnych można wyodrębnić dziewięć przyrostków w postaci inwariantów traktowanych jako sufiksy samodzielne. Część z nich to segmenty inwariantnie ekspresywne, czyli wyznaczające emocjonalne nacechowanie formacji w każdym możliwym kontekście słowotwórczym, np.: „-cio”, „-aszek”, „-uś”, ,-yczka”. Pozostałe sufiksy należą kontekstowo do przyrostków ekspresywnych, np.: ,-ek”, ,-ka”, ,-ko”, ,,-ina”/,-yna”, ,-iska”.

Biorąc pod uwagę stosunek procesu derywacji do procesu ekspresji, można w obrębie wynotowanych z kart tygodnika rzeczowników i przymiotników wyróżnić dominujące formacje ekspresywne prymarnie, w których derywacja posłużyła wyłącznie ekspresji emocji (np. „Panienka”, „Dzieciątko”, „Dziecina”, „proboszczyna”, „Jurcio”, „ludziska”, „Tatuś”, „siostrzyczka”), oraz - rzadsze - konstrukcje ekspresywne sekundarnie, nabywające afektywnego nacechowania przy okazji aktualizowania się innych funkcji sufiksu (np. „domek”, „kleryczek”, „Bernadetka”) (cf. Grabias 1981: 169-184). W obu grupach jednostek występują struktury będące wynikiem kojarzenia:

- neutralnego tematu słowotwórczego z dodatnim formantem ${ }^{14}, \mathrm{np}$. „domek”, „kleryczek”, „Bernadetka”, „Jurcio”, „ludziska”, ,proboszczyna";

- dodatniego aksjologicznie i/lub emocjonalnie (systemowo bądź konotacyjnie) tematu słowotwórczego z dodatnim formantem, np. „Panienka”, „Tatuś”.

Zespolenie dodatnio zabarwionego tematu słowotwórczego z sufiksem o takim samym nacechowaniu (typ drugi) potęguje niewątpliwie emocjonalny wydźwięk derywatu.

\footnotetext{
${ }^{14}$ Chodzi o zabarwienie formantu wyizolowanego z jakiegokolwiek kontekstu.
} 
Wyekscerpowane z „Przewodnika Katolickiego” ekspresywizmy morfologiczne są językowymi manifestacjami różnorodnych emocji, które umieścić można w obrębie takich grup uczuć, jak: podziw, duma, zachwyt, przyjemność, szacunek, sympatia, współczucie, wzruszenie ${ }^{15}$.

Wynotowanym z kart tygodnika emocjonalizmom morfologicznym można przypisać kilka podstawowych funkcji (cf. Wiatrowski 2010: 298-302). Ekspresja pozytywnych uczuć pozwala autorom osiągnąć komfort psychiczny. Wyrażając emocje, znajdują oni ujście dla własnego napięcia (funkcja katartyczna). Językowe wykładniki pozytywnych uczuć to także przekaźniki hierarchii wartości wyznawanych przez nadawców (funkcja kumulatywna). Obserwacja faktów werbalnych wyrażających uczucia daje więc możliwość ustalenia priorytetów ideologicznych, określenia aksjologicznych preferencji autorów. Analiza zebranego materiału pozwala na odtworzenie upowszechnianego na łamach „Przewodnika Katolickiego” systemu wartości, opierającego się przede wszystkim na wartościach etycznych, społecznych, poznawczych, pragmatycznych, które podporządkowane są - zgodnie z profilem ideowym tygodnika - nadrzędnej kategorii sakralnej ${ }^{16}$.

Uzewnętrznianie emocji służy ponadto konsolidowaniu wspólnoty komunikacyjnej tworzonej przez autorów i czytelników „Przewodnika Katolickiego" (funkcja socjalizująca). Jest to wspólnota konstytuowana tożsamością wartościowań, zbieżnym sposobem oglądu i interpretacji świata. Wyrażanie emocji pomaga również nadawcom w budowaniu pozytywnego obrazu siebie (funkcja autokreacyjna). Reakcja emocjonalna na różne fakty świadczy o dużej wrażliwości nadawców czasopisma, o ich zainteresowaniu rozmaitymi problemami, zaangażowaniu w sprawy dotyczące nie ich samych, lecz innych podmiotów czy większej grupy, społeczności, z którą nadawcy się utożsamiają. Nie ulega wątpliwości, że zabieg emocjonalizacji wypowiedzi wpływa na sugestywność i wiarygodność przekazu; aktualizuje się wówczas funkcja perswazyjna zastosowanych sygnalizatorów uczuć.

${ }^{15}$ Odwołuję się do propozycji stratyfikacyjnej Iwony Nowakowskiej-Kempnej (cf. 1995: 120-122).

${ }^{16}$ Odwołuję się do propozycji typologicznej Elżbiety Laskowskiej (cf. Laskowska 1993). 


\section{Literatura}

Bańko M., 2002, Wykłady z polskiej fleksji, Warszawa.

Bogusławski A., 1991, Polski sufiks -utki, „Poradnik Językowy” z. 5-6, s. 174-179.

Chlebda W., 1995, Cheops prozy, Pcim i Balceroid... Derywaty nazw własnych a leksykografia, „Poradnik Językowy” z. 2, s. 11-21.

Dobrzyński W., 1988, Z badań nad rozwojem polskich deminutywów II. Apelatywne spieszczenia dezintegralne, Warszawa-Wrocław.

Domin J., 2000, Stowotwórstwo hipokorystyków od imion własnych osobowych w języku polskim i rosyjskim, Słupsk.

Grabias S., 1980, Ekspresywność w strukturze znaczeniowej wypowiedzi, wyrazów i formantów, „Poradnik Językowy” z. 9-10, s. 476-488.

Grabias S., 1981, O ekspresywności języka. Ekspresja a słowotwórstwo, Lublin.

Grabias S., 2001, Język w zachowaniach społecznych, Lublin.

Grzegorczykowa R., 1978, Struktura semantyczna wyrażeń ekspresywnych, w: Z zagadnień słownictwa współczesnego języka polskiego, red. M. Szymczak, Wrocław, s. 117-123.

Grzegorczykowa R., Puzynina J., 1979, Słowotwórstwo współczesnego języka polskiego. Rzeczowniki sufiksalne rodzime, Warszawa.

Kosyl C., 1978, Metaforyczne użycie nazw własnych, w: Z zagadnień słownictwa współczesnego języka polskiego, red. M. Szymczak, Wrocław, s. 133-143.

Kreja B., 1969, Stowotwórstwo rzeczowników ekspresywnych w języku polskim. Formacje na -ik, -k-, -isko, i -ina, Gdańsk.

Kreja B., 1999, Słowotwórstwo polskie na tle słowiańskim, Studia, t. 2, Gdańsk.

Laskowska E., 1993, Wartościowanie w języku potocznym, Bydgoszcz.

Lubaś W., 2003, Polskie gadanie. Podstawowe cechy i funkcje potocznej odmiany polszczyzny, Opole.

Mikołajczuk A., 2000, Problem ocen w analizie wybranych polskich nazw uczuć z klasy semantycznej GNIEWU, w: Język a kultura, t. 14, Uczucia w języku i tekście, red. I. Nowakowska-Kempna, A. Dąbrowska, J. Anusiewicz, Wrocław, s. 117-134.

Nowakowska-Kempna I., 1995, Konceptualizacja uczuć w języku polskim. Prolegomena, Warszawa.

Siatkowska E., 1967, Deminutywa rzeczownikowe we współczesnych literackich językach zachodniosłowiańskich, „Studia z Filologii Polskiej i Słowiańskiej” t. 6, s. $157-170$.

Skubalanka T., 1972, O ekspresywności języka, „Annales UMCS. Sectio F” vol. 27, s. $123-135$.

Skubalanka T., 1973, Ekspresywność języka a mowa potoczna, w: Poetyka i stylistyka słowiańska, red. S. Skwarczyńska, Wrocław, s. 177-183.

Smółkowa T., 1989, Nominacja językowa. Na materiale nazw rzeczownikowych, Wrocław.

Wiatrowski P., 2010, Morfologiczne i leksykalne wykładniki negatywnych emocji w „Przewodniku Katolickim” z lat 1895-2005, Poznań. 
Wierzbicka A., 1968, Miejsce problematyki ekspresji w teorii semantycznej, „Pamiętnik Literacki" z. 4, s. 97-119.

Wierzbicka A., 1969, Problemy ekspresji. Ich miejsce w teorii semantycznej, w: eadem, Dociekania semantyczne, Wrocław, s. 33-61. 